\title{
DETERMINATION OF PREDICTIVE ANATOMIC PARAMETERS FOR BLEEDING OF BRAIN ARTERIOVENOUS MALFORMATIONS BY MULTIDETECTOR CT ANGIOGRAPHY
}

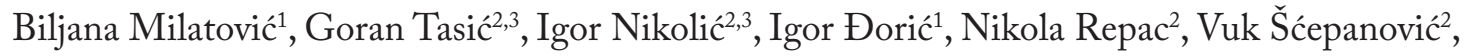 \\ Aleksandar Janićijević 2 , Krešimir Rotim ${ }^{4,5}$ and Lukas Rasuliće ${ }^{2,3}$ \\ ${ }^{1}$ Neuroradiology Department, Center for Radiology and MRI, Clinical Center of Serbia, Belgrade, Serbia; \\ ${ }^{2}$ Clinical Department of Neurosurgery, Clinical Center of Serbia, Belgrade, Serbia; ${ }^{3}$ School of Medicine, \\ University of Belgrade, Belgrade, Serbia; ${ }^{4}$ Clinical Department of Neurosurgery, Sestre milosrdnice \\ University Hospital Center, Zagreb, Croatia; ${ }^{5}$ University of Applied Health Sciences, Zagreb, Croatia
}

SUMMARY - Patients with brain arteriovenous malformation (AVM) have a certain risk to bleed, and the goal of this study was to examine the effect of radiological and clinical predictive characteristics of AVM hemorrhage using multidetector computed tomographic (MDCT) angiography. The study included a series of 57 patients, mean age 35.46 years, who were diagnosed during their hospitalization at Clinical Department of Neurosurgery, Clinical Center of Serbia, in the period from January 2008 to March 2016. In all patients, the diagnosis was made using MDCT angiography. Two groups of patients were observed. The first group included patients who did not initially present with hemorrhage, while the second group initially presented with hemorrhage. Both groups were treated with medical therapy or a combination of medical therapy with embolization/surgery/radiotherapy. Deep venous drainage $(\mathrm{p}<0.05)$, combined arterial supply from different basins $(\mathrm{p}<0.05)$ with a length $>60 \mathrm{~mm}$, venous dilatation present in the drainage vein $(\mathrm{p}<0.01)$, and the angle of casting supply arteries in the nidus $(\mathrm{p}<0.01)$ carry a risk of repeated bleeding. In the group of patients who had initial hemorrhage, the mean value of the casting angle size was $130^{\circ}$, while in the group that did not have initial bleeding the mean value of the measured angle size was $103.81^{\circ}$ with standard deviation of $17.21^{\circ}$ ( $\mathrm{p}<0.01$ ). In conclusion, AVMs with deep venous drainage from the carotid and vertebrobasilar basin, the length of the feeding arteries $>60 \mathrm{~mm}$, the angle of the casting feeding arteries in the nidus $\geq 130^{\circ}$ and dilatation and/or venous aneurysm of drainage vessel are predictive for clinical presenting by hemorrhage.

Key words: Intracranial arteriovenous malformations - diagnostic imaging; Intracranial arteriovenous malformations - anatomy and histology; Cerebral hemorrhage; Risk factors; Multidetector computer tomography - methods; Angiography - methods

\section{Introduction}

Brain arteriovenous malformations (AVMs) are considered to be congenital, usually solitary anomalies

Correspondence to: Lukas Rasulić, $M D, P h D$, Clinical Department of Neurosurgery, Clinical Center of Serbia, Koste Todorovića 4, Belgrade, Serbia

E-mail: lukas.rasulic@gmail.com

Received May 12, 2016, accepted November 28, 2017 of the central nervous system. The first descriptions of vascular malformations date from $\mathrm{BC}$ to the year 1500 , and as a separate entity were confirmed in the $19^{\text {th }}$ century ${ }^{1,2}$. AVM makes a web of pathologic vascular ducts, which consists of one or more of the feeding arteries, arterial inlet blood vessels, arteriovenous nidus, and varicose vein drain. Analysis of a large series of autopsy findings found the incidence of AVMs to range from $0.04 \%$ to $0.52 \% \%^{3,4}$. The dominant way of presenting the 
AVM is hemorrhage (60\%), epilepsy (25\%-30\%), and less likely Nanto headaches and neurologic deficit ${ }^{2,5,6}$. Patients who initially present intracranial AVM with hemorrhage have a significant rate of morbidity and mortality, as well as the possibility of rebleeding later in life ${ }^{7}$. According to autopsy studies, only $12 \%$ of AVMs become symptomatic during life ${ }^{6}$.

Localization, morphology and structure of blood vessels of AVM evaluated by radiologic techniques of multidetector computed tomographic (MDCT) angiography allow precise evaluation of AVM, as well as consequent determination of optimal, most often multidisciplinary therapeutic approach.

The aim of our research was to show anatomic features that are predictors of AVM rupture and hemorrhage by use of MDCT angiography techniques.

\section{Patients and Methods}

The study included a series of 57 patients (29 men and 28 women) with AVM diagnosed during hospitalization at Clinical Department of Neurosurgery, Clinical Center of Serbia, Belgrade, in the period from January 2008 to March 2016. In all patients, the diagnosis of AVM was set using MDCT angiography. $\mathrm{Pa}-$ tient monitoring began at the time of AVM diagnosis. Patient follow up was completed in March 2016, when we started statistical analysis.

For presentation and evaluation of clinical and anatomic characteristics of AVM, the generally accepted system by Spetzler and Martin (SM index score) was used, which involves assessment of the location, size and type of AVM drainage (superficial, deep or combined), as well as the final value of collective gradation. Morphological characteristics of AVM were determined by measuring anatomic parameters (size, diameters and angles) by use of the Siemens Definition 128 software. The methods of descriptive and analytical statistics were used to test statistical significance and check the study hypotheses.

\section{Results}

Keeping in mind the basic objectives and hypotheses of our research, the primary interest was to investigate the possible anatomic parameters as predictors of bleeding AVM. That is why the patients were di-
Table 1. Morphological characteristics of arteriovenous malformations

\begin{tabular}{|c|c|c|c|}
\hline & \multicolumn{2}{|c|}{ Hemorrhage } \\
\hline & & No & Yes \\
\hline \multirow[t]{2}{*}{ Arterial aneurysm } & No & 16 & 13 \\
\hline & Yes & 5 & 23 \\
\hline \multirow[t]{3}{*}{ Arterial distance } & Long $(\geq 6 \mathrm{~cm})$ & 9 & 33 \\
\hline & $\begin{array}{l}\text { Medium } \\
(3-6 \mathrm{~cm})\end{array}$ & 9 & 3 \\
\hline & Short $(\leq 3 \mathrm{~cm})$ & 3 & 0 \\
\hline \multirow[t]{2}{*}{ Venous dilatation } & No & 17 & 4 \\
\hline & Yes & 4 & 32 \\
\hline \multicolumn{2}{|c|}{$\begin{array}{l}\text { Angle of inclination } \\
(\chi \pm S D)\end{array}$} & $\begin{array}{l}103.81^{\circ} \\
\pm 17.21^{\circ}\end{array}$ & $\begin{array}{l}130^{\circ} \\
\pm 13.65^{\circ}\end{array}$ \\
\hline \multirow[t]{3}{*}{ Drainage } & Deep & 0 & 11 \\
\hline & Mixed & 9 & 13 \\
\hline & Superficial & 12 & 12 \\
\hline
\end{tabular}

vided into two groups. One group included patients that initially presented with AVM bleeding, while the other group included patients that initially presented with different events (headache/epileptic seizure). In the group with initial hemorrhage, a slight predominance of the vertebrobasilar (VB) basin was noticed, which was recorded in $54 \%$ of patients, while the incidence of carotid siphon was recorded in $46 \%$ of patients (Utest-498; $\mathrm{p}<0.05$ ).

In the group of patients that had initial hemorrhage, the presence of deep drainage was noticed in $31 \%$, mixed drainage in $36 \%$, and superficial drainage in $33 \%$ of cases (Utest-238; $\mathrm{p}<0.05$ ). In the group of patients that did not have initial bleeding the existence of deep drainage was not observed.

In the group of patients with initial hemorrhage, the predominant presence of venous dilatation was recorded in $89 \%$ of patients, while in the group of patients without initial hemorrhage it was observed in $11 \%$ of patients (Utest-642; $<<0.01$ ).

In the group of patients who had initial hemorrhage, the predominant presence of arterial aneurysms was noticed in $64 \%$ of patients. In patients in which the AVM initially presented by other events, the existence of arterial aneurysms in the inlet blood vessel was observed in $18 \%$ of cases (Utest-529; $\mathrm{p}<0.01$ ).

The long inlet artery $(\geq 6 \mathrm{~cm})$ was observed in approximately $92 \%$ of patients in which the AVM pre- 
sented by hemorrhage, and in $21 \%$ of patients in which the AVM was not presented by hemorrhage (Utest-189; $\mathrm{p}<0.01$ ).

In the group of patients who had initial hemorrhage, the mean size of the angle was $130^{\circ}$, with standard deviation of $13.65^{\circ}$, while in the group who did not have initial bleeding the mean size of the measured angle was $103.81^{\circ}$ with standard deviation of $17.21^{\circ}$ (Utest-655; $\mathrm{p}<0.01$ ).

Statistical analysis yielded no significant differences between the two groups of patients according to the AVM size ( $p>0.05)$. Multifactor analysis of the characteristics observed indicated that the following characteristics with factorial load greater than 0.7 and multiple regression model could be marked as statistically significant predictors of bleeding AVM: presence of arterial aneurysms $(0.701 ; \mathrm{p}<0.01)$; type of drainage $(0.719 ; \mathrm{p}<0.01)$; length of arterial supply $(0.756$; $\mathrm{p}<0.05)$; angle of blood inflow $(0.778 ; \mathrm{p}<0.01)$ and presence of venous dilatation $(0.793 ; \mathrm{p}<0.01)$.

\section{Discussion}

Regardless of the relatively simple AVM diagnosis by MDCT angiography and an increasing number of incidentally detected AVMs, they continue to represent a major challenge considering that therapeutic approach is usually multidisciplinary. The use of MDCT angiography enables display of almost the entire intracranial vascularization in a relatively simple manner. Due to the necessity of the highest possible resolution device with 64 rows of detectors in which we collect data, the Definition Siemens 128 meets the needs of MDCT angiography and technical performance of the device can be modified to the needs of the examination. It should be noted, however, that MDCT angiography does not have spatial resolution like digital subtraction angiography (DSA) but in the future, MDCT angiography may be complementary to DSA in a substantial number of patients with acute hemorrhage which require prompt diagnosis and early endovascular treatment.

High sensitivity and specificity, the ability to accurately detect the structure of blood vessels, excellent spatial resolution, selective capture of all three phases, superiority in determining the contours and the relationship to the surrounding vascular structures, and the possibility of performing endovascular treatment in the same act make DSA still the most important method in the diagnosis of $\mathrm{AVM}^{8}$. DSA remains the 'gold standard' in the evaluation of AVM'.

Understanding the morphology and structure of blood vessels is a key factor in the evaluation of possible hemorrhage and re-hemorrhage. Spetzler-Martin grading system provides statistical confirmation for reconciling the opinions of neurosurgeons and neuroradiologists in terms of morphological characteristics of AVM.

In terms of the size of malformations, neurosurgeons are more likely to estimate preoperatively the diameter of malformation and the overall value of the SM score higher as compared to neuroradiologists. Disagreement is also manifested in the estimation of the type of drainage, especially in case of malformation which has a small deep drainage vein and dominant wide superficial vein ${ }^{10}$. Localization of AVM is also difficult to assess in borderline cases, i.e. in the zones that are in the surroundings to the so-called eloquent areas of the brain.

The importance of the supply of arterial blood vessels in AVM has been highlighted in the literature because it is easily differentiated by the methods of MDCT angiography and DSA. AVM arteries are pathologically and pathophysiologically different from the arteries that have appropriate structure and morphology.

They can participate in the structure of AVM in three main forms: the arteries that end within the AVM, called terminal arteries; transit artery with branches participating in the construction of AVM; and transient artery that is only passing through the AVM but not taking part in its structure. Analyzing AVM, Yasargil says that there are 60 possible combinations of arterial supply of blood vessels for each lesion $^{11}$. The biggest drop in the system pressure occurs at the turn of the feeder AVM. A certain indication of the presence of the 'steal' phenomenon is the length of the arterial supply greater than $8 \mathrm{~cm}$, measured from the circle of Willis ${ }^{12}$, localization in the eloquent brain zone or in the posterior cranial fossa, arterial supply of the VB siphon ( $\mathrm{p}<0.01)$, feeder length greater than 60 $\mathrm{mm}$, drainage of the blood vessel dilation, and blood flow angle of inclination relative to the AVM which is bleeding of $\geq 130^{\circ} 13$.

Patients who experience bleeding from AVMs are at a risk of recurrent bleeding. In most series, it ranges 
from $3 \%$ to $4 \%$. The value obtained was in accordance with the results reported by Forster et al. ${ }^{14}$, Spetzler and Martin ${ }^{15,16}$, Spetzler et al. ${ }^{16}$, and Tasic et al. ${ }^{17}$. Nusbaum et al. state that the risk of hemorrhage is identical with AVM that were presented by bleeding and those that did not, amounting to $3 \%-4 \%$ per year ${ }^{18}$.

Drainage veins have 6-10 times greater distensibility of artery supply and can contain three-fold greater volume of blood than the artery, and their compliance is 18-30 times higher than that of the artery ${ }^{19}$. The results obtained confirmed the importance of the type of venous drainage from the AVM as a predisposing factor for the occurrence of bleeding.

\section{Conclusion}

From the above, we can conclude that the risk of bleeding is present in AVMs that are localized in the eloquent area of the brain, with combined drainage from the carotid and VB basin, and only from VB basin, the length of the feeding arteries $>60 \mathrm{~mm}$, angle separation of feeding arteries in relation to the nidus $\geq 130^{\circ}$, associated artery aneurysm on the inlet artery which is closer than $20 \mathrm{~mm}$, the presence of one or more intranidal aneurysms with deep or mixed venous drainage and dilatation and/or aneurysm of venous drainage vessel.

\section{References}

1. Kandai S, Abdullah MS, Naing NN. Angioarchitecture of brain arteriovenous malformations and the risk of bleeding: an analysis of patients in northeastern Malaysia. Malays J Med Sci. 2010;17(1):44-8.

2. Courville CB, Pathology of the Central Nervous System: A Study Based Upon a Survey of Lesions Found in a Series of Forty Thousand Autopsies. $3^{\text {rd }}$ edn. Mountain View, CA, USA: Pacific Press Publishing Association; 1950.

3. Mc Cormick WF. Pathology of vascular malformations of the brain. In: Wilson CB, Stein BM, editors. Intracranial Arteriovenous Malformations. Baltimore: Williams \& Wilkins, 1984; p. 44.

4. Henkes H, Gotwald GT, Brew S, Miloslavski E, Kämmerer F, Kühne D. Intravascular pressure measurements in feeding pedicles of brain arteriovenous malformations. Neuroradiology. 2006;48(3):182-9. doi: 10.1007/s00234-005-0022-7.

5. Yasargil MG, Microneurosurgery. Vol. IIIA. Stuttgart: Georg Thieme Verlag, 1987.
6. McCormick WE. Classification, pathology and natural history of angiomas of the central nervous system. Weekly Update: Neurology and Neurosurgery. 1978;14:2-7.

7. Brown RD, Wiebers DO, Torner JC, O Falon WM. Frequency of intracranial hemorrhage as a presenting symptom and subtype analysis: a population-based study of intracranial vascular malformations in Olmsted County, Minnesota. J Neurosurg. 1996;85:29-32.

8. Tanoue S, Kiyosue H, Kenai H, Nakamura T, Yamashita M, Mori $\mathrm{H}$. Three-dimensional reconstructed images after rotational angiography in the evaluation of intracranial aneurysms: surgical correlation. Neurosurgery. 2000;47(4):866-71.

9. Hochmuth A, Spetzger U, Schumacher M. Comparison of three-dimensional rotational angiography with digital subtraction angiography in the assessment of ruptured cerebral aneurysms. Am J Neuroradiol. 2002;23(7):1199-205.

10. Al-Shahi R, Pal N, Lewis SC, Bhattacharya JJ, Sller RJ, Warlow CP. Observer agreement in the angiographic assessment of arteriovenous malformations of the brain. Stroke. 2002;33: 1501-8. doi: 10.1161/01.STR.0000018318.83802.18.

11. Yasargil MG. Microneurosurgery. Vol. IIIB. Stuttgart: Georg Thieme Verlag, 1988.

12. Nornes H. Quantitation of altered hemodynamics. In: Wilson $\mathrm{CB}$, Stein BM, editors. Intracranial Arteriovenous Malformations. Baltimore: Williams \& Wilkins, 1984; p 32-43.

13. Abla AA, Nelson J, Rutledge WC, Young WL, Kim H, Lawton MT. The natural history of AVM hemorrhage in the posterior fossa: comparison of hematoma volumes and neurological outcomes in patients with ruptured infra- and supratentorial AVMs. Neurosurg Focus. 2014;37(3):E6. doi: 10.3171/2014.7.FOCUS14211.

14. Forster DMC, Steiner L, Hakanson S. Arteriovenous malformations of the brain. A long-term clinical study. J Neurosurg. 1972;37:562-70.

15. Spetzler RF, Martin MA. A proposed grading system for arteriovenous malformations. J Neurosurg. 1985;65:476-83.

16. Spetzler RF, Martin NA, Carter LP, Flom RA, Raudzens PA, Wilkinson E. Surgical management of large AVMs by staged embolization and operative excision. J Neurosurg. 1987;67: 17-28.

17. Tasic G, Jovanovic V, Djurovic B, Nikolic I, Janicijevic M, Samardzic M, Antunovic V, Bogosavljevic V. Natural course of the arteriovenous malformations of the brain initially presented by hemorrhage: analysis of a clinical series of 39 patients. Turk Neurosurg. 2011;21(3):280-9. doi: 10.5137/1019-5149.JTN.3320-10.1.

18. Nusbaum ES, Heros RC, Camarata PJ. Surgical treatment of intracranial arteriovenous malformations with an analysis of cost-effectiveness. Clin Neurosurg. 1995;42:348-69.

19. Folkow B, Sivertsson R. Adaptive changes in „reactivity“and volumen ratio in cat blood vessels exposed to prolonged transmural pressure difference. Life Sci. 1968;7(Part I):1283-9. 


\title{
Sažetak
}

\section{ODREĐIVANJE PREDIKTIVNIH ANATOMSKIH PARAMETARA ZA KRVARENJE ARTERIOVENSKIH MALFORMACIJA MOZGA POMOĆU MULTIDETEKTORSKE CT ANGIOGRAFIJE}

\author{
B. Milatović, G. Tasić, I. Nikolić, I. Đoric, N. Repac, V. Š́épanović, A. Janićijevic, K. Rotim i L. Rasulić
}

Bolesnici s arteriovenskim malformacijama mozga (AVM) imaju određen rizik za krvarenje pa je cilj ove studije bio ispitati utjecaj radioloških i kliničkih prediktivnih karakteristika AVM za hemoragiju pomoću multidetektorske CT angiografije (MDCTA). U studiju je bilo uključeno 57 bolesnika srednje dobi od 35,46 godina kojima je dijagnoza postavljena na Institutu za radiologiju i magnetskom rezonancijom dok su bili hospitalizirani na Klinici za neurologiju Kliničkog centra Srbije u razdoblju od siječnja 2008. do ožujka 2016. godine. Svim bolesnicima je dijagnoza postavljena pomoću MDCTA. Praćene su dvije skupine bolesnika. Jednu skupinu činili su bolesnici kod kojih se AVM u početku nije manifestirala krvarenjem, dok se druga skupina odmah prezentirala hemoragijom. Obje skupine su liječene medikamentnom terapijom ili kombinacijom medikamentne terapije $\mathrm{s}$ embolizacijom/kirurškom intervencijom/radioterapijom. Duboka venska drenaža $(\mathrm{p}<0,05)$, kombinirani arterijski dovod iz različitih slivova $(\mathrm{p}<0,05)$ s dužinom $>60 \mathrm{~mm}$, prisutna venska dilatacija na drenažnoj veni $(\mathrm{p}<0,01)$ i kut ulijevanja dovodnih arterija u nidus $(\mathrm{p}<0,01)$ nosili su rizik ponovljenog krvarenja. U skupini bolesnika koji su imali inicijalnu hemoragiju srednja vrijednost veličine kuta ulijevanja je bila $130^{\circ}$, dok je u skupini koja nije imala inicijalno krvarenje srednja vrijednost izmjerenog kuta bila $103,81^{\circ}$ sa standardnom devijacijom $17,21^{\circ}(p<0,01)$. U zaključku, AVM s dubokom venskom drenažom iz karotidnog i vertebrobazilarnog sliva, dužinom dovodne arterije $>60 \mathrm{~mm}$, kutom ulijevanja dovodne arterije $\mathrm{u}$ nidus $\geq 130^{\circ}$ i dilatacijom $\mathrm{i} / \mathrm{ili}$ aneurizmom drenažne vene su prediktivni model za kliničko prezentiranje hemoragijom.

Ključne riječi: Intrakranijske arteriovenske malformacije - dijagnostičko snimanje; Intrakranijske arteriovenske malformacije - anatomija i histologija; Cerebralno krvarenje; Rizični čimbenici; Multidetektorska tomografja, kompjutorizirana - metode; Angiografija - metode 